\title{
WEED INFESTATION OF SPRING COMMON WHEAT (Triticum aestivum L.) GROWN IN MONOCULTURE DEPENDING ON THE COVER CROP AND WEED CONTROL METHOD
}

\author{
Dorota Gawęda, Cezary A. Kwiatkowski \\ Department of Herbology and Plant Cultivation Techniques, University of Life Sciences in Lublin \\ Akademicka 13, 20-950 Lublin, Poland \\ e-mail: dorota.gaweda@up.lublin.pl
}

Received: 05.10.2012

\begin{abstract}
The aim of this 3-year field study was to evaluate the effect of some stubble crops and in-crop weed control methods on the species composition, number and air-dry weight of weeds in a wheat crop grown in short-term monoculture. The study was conducted in the period 2009-2011 in the Uhrusk Experimental Farm on mixed rendzina soil classified as very good rye soil complex. It included various types of stubble crops ploughed in each year (control treatment without cover crop, white mustard, lacy phacelia, a mixture of legumes - narrow-leaf lupin + field pea) and methods of weed control in spring wheat (mechanical, mechanical and chemical, chemical weed control). On average during the study period, all stubble crops used reduced the air-dry weight of weds in the treatments with mechanical weed management relative to the control treatment. Irrespective of the weed control method, the number of weeds in the wheat crop was significantly lower only after the ploughing in of white mustard. Mechanical weed management proved to be less effective in reducing the number and dry weight of weeds compared to other weed control methods. The white mustard and legume mixture cover crops had a reducing effect on the number of weed species in relation to the treatment without cover crops. The highest floristic diversity of weed communities was found in the spring wheat crop in which only mechanical weeding alone was used.
\end{abstract}

Key words: Triticum aestivum, number of weeds, air-dry weight of weeds, stubble crop, weed control

\section{INTRODUCTION}

The percentage of cereals in the crop structure is now more than $70 \%$ and, as a result of that, they are often grown in the same field year after year. This causes the occurrence of a number of negative phenomena, among others the deteriorated phytosanitary condition of plants and soil nutrient depletion. Increased weed infestation and the compensation of troublesome species are often a consequence of these adverse changes in agroecosystems caused by monoculture. The introduction of cover crops is one of the methods of mitigating the negative effects of continuous cropping (W ojci e chowski, 1998). Growing cover crops as green manure that is ploughed in, which improves the quality of the soil environment with relatively low outlays, is gaining special importance (D u e r , 1994). Dense cover crops reduce weed infestation ( $\mathrm{T}$ e a s d a le et al. 1991; H a u g g a a r d- Niels en et al. 2001; G a w ę d a , 2009) and also affect the soil and the succeeding crop through the secretion of biologically active substances and compounds that are released during the decomposition of cover crop biomass. This applies in particular to species of the family Brassicacae which contain chemical compounds inhibiting seed germination of other plants and subsequently their growth, and which therefore can be used to reduce weed infestation. The allelopathic potential of these plants is manifested mainly in dead stems and leaves and it is higher when plant remains are mixed with the soil $(\mathrm{Ole} \mathrm{s} \mathrm{ze} \mathrm{k} \mathrm{et}$ al. 1994). Reduced weed infestation of spring cereal crops under the influence of stubble crops ploughed in before winter have been shown, among others, by the studies of J a s kulski et al. (2000), K w i a t k ow ski (2009), and Wojciechowski (2009). The studies of Duer (1994) as well as Kuś and Joń c zyk (1999) have demonstrated that soil mulching with cover crops for the winter period, compared to the ploughing in of such crops before winter, increases weed infestation and reduces crop plant yields. Thus, the ploughing in of cover crop biomass has proved to be a more beneficial method for counteracting the negative effects of continuous cereal cropping. 
A hypothesis was formulated on the basis of the results of existing research that stubble crops ploughed in before winter would compensate for the negative effects of growing spring wheat after itself, contributing to reduced weed infestation of this crop plant. To verify this assumption, a study was conducted to evaluate the effects of some stubble crops and in-crop weed control methods on the species composition, number and air-dry weight of weeds in a wheat crop grown in short-term monoculture.

\section{MATERIALS AND METHODS}

A field experiment was conducted during the period 2009-2011 in the Uhrusk Experimental Farm belonging to the University of Life Sciences in Lublin.

The experiment was established on mixed rendzina soil classified as very good rye soil complex. The soil showed an alkaline $\mathrm{pH}(\mathrm{pH}$ in $1 \mathrm{~mol} \mathrm{KCl}=7.5)$. It was characterized by very high availability of phosphorus $(141.8 \mathrm{mg} \mathrm{P} \times 1 \mathrm{~kg}$ of soil) and potassium (221.7 $\mathrm{mg} \mathrm{K} \times 1 \mathrm{~kg}$ of soil) as well as very low magnesium availability ( $19 \mathrm{mg} \mathrm{Mg} \times 1 \mathrm{~kg}$ of soil). The humus content was at a level of $1.7 \%$, whereas the content of fines in the $0-30 \mathrm{~cm}$ layer was $25.5 \%$.

The experiment was set up as a split-plot design, in three replications. The sown area of the plot was $35 \mathrm{~m}^{2}$, while the harvested area was $24 \mathrm{~m}^{2}$. In the present trial, spring common wheat (Triticum aestivum L.), cv. 'Bombona', was grown in monoculture after itself. The wheat monoculture was established in 2009, in a field after spring barley; after the barley crop was harvested, the stubble crops were ploughed in.

Experimental factors:

I. Type of stubble crop:

- without cover crop (control treatment);

- white mustard (Sinapis alba L.);

- lacy phacelia (Phacelia tanacetifolia Benth.);

- mixture of legumes: narrow-leaf lupin (Lupinus angustifolius L.) + field pea (Pisum sativum L.).

II. Method of weed control in the spring wheat crop:

- mechanical weed control (harrowing: at the cracking stage and at the 3-4 leaf stage);

- mechanical and chemical weed control (harrowing at the 3-4 leaf stage and herbicide application);

- chemical weed control (herbicide application).

In the plot without cover crop (control treatment), skimming and double harrowing were performed after the harvest of wheat, while before winter ploughing was done to a depth of about $25 \mathrm{~cm}$. Each year, the stubble crops were sown in the second decade of August after the harvest of wheat. Tillage for stubble crops involved single ploughing and pre-sowing tillage using a seedbed cultivator consisting of a spring-tine harrow and cage roller. Cover crop plants were seeded in the following amounts: white mustard $15 \mathrm{~kg} \times \mathrm{ha}^{-1}$, lacy phacelia $10 \mathrm{~kg} \times \mathrm{ha}^{-1}$, field pea and narrow-leaf lupin $100 \mathrm{~kg} \times \mathrm{ha}^{-1}$ each. Each year in the third decade of October, the stubble crops were ploughed under to a depth of $25 \mathrm{~cm}$ before winter.

Cover crop biomass was determined at the end of October (before the stubble crops were ploughed in). Whole plants were pulled out from a $1 \mathrm{~m}^{2}$ area in each plot. After their air-dry weight was determined, the mean value for the individual stubble crops was calculated.

Spring wheat was sown in the first decade of April, at a rate of $220 \mathrm{~kg} \times \mathrm{ha}^{-1}\left(550\right.$ plants $\left.\times \mathrm{m}^{-2}\right)$.

Pre-sowing tillage for wheat included the following: harrowing and additional soil preparation using a seedbed cultivator consisting of a spring-tine harrow and cage roller. Before sowing, seeds were dressed with the seed dressing Oxafun T 75 DS/WS (tiuram + carboxin) at a rate of $200 \mathrm{~g}$ per $100 \mathrm{~kg}$ of seed.

Mineral fertilization was applied before sowing the cereal crop. Fertilizer rates were determined on the basis of nutritional requirements of the crop plant and soil nutrient availability. NPK rates were as follows: $\mathrm{N}-70 \mathrm{~kg} \times \mathrm{ha}^{-1}$ (ammonium nitrate $\left.34.5 \%\right) ; \mathrm{P}-26 \mathrm{~kg}$ $\times$ ha $^{-1}$ (superphosphate $40 \%$ ); K $-33 \mathrm{~kg} \times$ ha $^{-1}$ (potassium salt $60 \%$ ). In the treatments with chemical weed control as well as with mechanical and chemical weed control, the following herbicides were applied at the beginning of the tillering stage (BBCH 21): Chwastox Turbo $340 \mathrm{SL}$ (MCPA + dicamba) at a rate of 2.01 $\times$ ha $^{-1}+$ Puma Uniwersal 069 EW (fenoxaprop-P-ethyl + mefenpyr-diethyl) at a rate of $1.21 \times$ ha $^{-1}$. In all the experimental treatments, the growth retardant Cerone $480 \mathrm{SL}$ (ethephon) was used at a rate of $1.01 \times \mathrm{ha}^{-1}$ at the 2nd node stage (BBCH 32). At the beginning of stem elongation (BBCH 30), the fungicide Alert 375 SC (flusilazole + carbendazim) was applied at a rate of $1.01 \times$ ha $^{-1}$ across the whole experiment.

Weed infestation was determined by the dry-weight-rank method at the beginning of the stem elongation stage (BBCH 31). Evaluation of weed infestation consisted in collecting weeds from an area of $1 \mathrm{~m}^{2}$ and determining their botanical composition, density and air-dry weight. The sampling area was delineated by a frame of $1 \mathrm{~m} \times 0.5 \mathrm{~m}$ in two randomly selected points of each plot. The results obtained from individual replications were averaged and the values for the respective treatments were presented.

The obtained results for the number and air-dry weight of weeds were statistically analysed using analysis of variance, while the significance of differences was estimated by Tukey's test. Coefficients of 
correlation between grain yield and number and air-dry weight of weeds as well as between air-dry weight of stubble crops and air-dry weight of weeds in the spring wheat crop were also calculated.

Throughout the study period, mean air temperature during the growing season of spring wheat (IV-VIII) was higher than the long-term mean by, respectively, $0.7^{\circ} \mathrm{C}$ in $2009,1.9^{\circ} \mathrm{C}$ in 2010 , and $1.5^{\circ} \mathrm{C}$ in 2011. Air temperature in individual months during the period 2009-2011 was generally higher than the long-term average temperature. Lower temperature was recorded only in May (by $0.5^{\circ} \mathrm{C}$ ) and in June (by $0.2^{\circ} \mathrm{C}$ ) in 2009 (Table 1).

In all study years, total rainfall during the growing season of spring wheat (IV-VIII) much exceeded the long-term mean by, respectively, $45.5 \mathrm{~mm}$ in 2009 , $108.5 \mathrm{~mm}$ in 2010 , and $40.2 \mathrm{~mm}$ in 2011. In all experimental years, lower rainfall was recorded in the month when spring wheat was sown (IV), compared to the long-term average for this month. In 2009 this difference was as much as $12.1 \mathrm{~mm}$. Rainfall lower than the long-term average was also recorded in July and August 2009, June and July 2010 as well as in May and August 2011. Taking into account particular months of the growing season during the duration of the experiment, the most abundant rainfall was recorded in June 2009, May 2010, and July 2011 (Table 1).

\section{RESULTS AND DISCUSSION}

On average during the three-year study period, the white mustard cover crop significantly reduced the number of weeds (by 3.7 plants $\times \mathrm{m}^{-2}$ ) compared to the control treatment (Table 2). The ploughing in of lacy phacelia proved to be the least beneficial. After this cover crop, the number of weeds was significantly higher than that found after white mustard (by 6.3 plants $\times \mathrm{m}^{-2}$ ) and the legume mixture (by 5.0 plants $\times \mathrm{m}^{-2}$ ). The reducing effect of the ploughed-in cover crops on weed density in the wheat crop became evident in the third year of the experiment. After white mustard and the mixture of lubin and pea, the value of the trait in question was significantly lower by 69.3 and $36.3 \%$, respectively, compared to that found in the treatment without cover crop.

The positive role in weed control of the white mustard stubble crop in cereal crops is also confirmed by the results of the studies of D w o rakowski (1998), Kwiatkowski (2004), and Gaw ęd a (2009). On the other hand, W oj ciechows ki (2009) showed that after the ploughing in of white mustard the number of weeds in a spring wheat crop remained at a similar level as in the treatment without cover crops. This author's study demonstrated that a mixture of legumes with oats had a beneficial effect on reducing weed infestation of the succeeding crop; after the ploughing in of the legume crop, the number of weeds was lower by $11.4 \%$ compared to the treatment without cover crop and lower by $16.6 \%$ than that found after the ploughing in of white mustard. W o ź $\mathrm{n}$ i a k (2005) obtained different results in his research. In a spring wheat monoculture, this author found an increase in the number and weight of weeds after the ploughing in of undersown crops (Westerwolds ryegrass and serradella) relative to the control treatment.

The weed control method significantly differentiated the number of weeds in the spring wheat crop (Table 2). In the treatments where harrowing was the only weed removal procedure, nearly threefold higher numbers of weeds were found compared to the plots with mechanical and chemical weed control as well as with chemical weed control alone. In the successive years of the experiment, the highest number of weeds was recorded in the crops in which only mechanical weeding was used.

On average during the three-year study period, the crops of spring wheat grown after itself without cover cropping and with lacy phacelia, where mechanical weed control was used in both these treatments, were characterized by the highest number of weeds (Table 2). The other treatments effectively reduced the numbers of weeds in spring wheat relative to these plots.

On average for the three-year study period, a significant reduction was recorded in air-dry weight of weeds in the spring wheat crops after all stubble crops used compared to the control treatment (Table 3). In spring wheat sown after lacy phacelia and the legume mixture, weed dry weight was more than twice lower, while in the crop after white mustard more than three times lower than in the treatment without cover crops. A declining trend in weed dry weight after the ploughing in of all stubble crops was observed already in the first year of wheat growing. In the next years of continuous cropping of wheat, this decline was confirmed statistically. K w i a t k ow s ki (2009) also showed in all study years a reduction in weed infestation in a spring barley monoculture after the ploughing in of white mustard biomass in relation to the treatment without cover crop.

Mechanical weed management of spring wheat was less effective compared to mechanical and chemical weed control as well as to chemical weed control alone (Table 3). On average during the three-year study period, weed dry weight was lower by $88.4 \%$ in the wheat crop where mechanical weed removal and herbicides were used, whereas in the plots with chemical weed control it was lower by $83.7 \%$ relative to the treatments with mechanical weed control. In the next years of wheat cultivation, a successive increase in weed dry weight was observed in the plots where weed management involved only harrowing, compared to the other weed control methods. 
The present study proves that the application of mechanical weed control alone and, simultaneously, the ploughing in of cover crops in spring wheat cultivation produce positive effects resulting in a significant reduction in weed infestation relative to mechanically weeded plots without cover crop (Table 3 ).

During the study period, a total of 35 weed species inhabited the spring wheat crops, including 25 annual ones, while the other species were perennial weeds (Table 4). Avena fatua dominated in the treatment without cover crops. Echinochloa crus-galli also occurred in quite large numbers. The highest number of individuals of Fallopia convolvulus, Veronica persica, and Polygonum aviculare was found in the spring crop sown in the plots with white mustard biomass ploughed in. The species Veronica persica also occurred in greatest numbers in the treatment with the legume mixture. Setaria viridis was the dominant weed species in the plots with lacy phacelia as a cover crop. Veronica persica and Chenopodium album also occurred numerously. In the opinion of K w i a t k o w s k i (2009), cover cropping may result in the compensation of some weed species in a spring wheat crop. This is confirmed by the present study in which all the stubble crops used increased the numbers of the species Veronica persica dominant in the spring crop, compared to the treatment without cover crop. On the other hand, the higher numbers of Avena fatua and Echinochloa crus-galli were found in the wheat crop grown without the regenerating plant, compared to the plots with cover crops. Therefore, this shows that cover crops reduced or enhanced the increase in the number of dominant weed species in relation to the control treatment, which is evidence of the complexity of their effects on weed infestation. This is confirmed, among others, by the studies of $\mathrm{Te}$ a s d a le et al. (1991) and A ke mo et al. (2000).

Among the cover crops in question, the ploughing in of white mustard and the legume mixture of narrow-leaf lupin with field pea had a reducing effect on the number of weed species in relation to the control treatment (Table 4).

The method of weed control in spring wheat affected the species composition of weeds occurring in the crops of this plant (Table 4). The highest number of weeds was found in the wheat crop where mechanical weed management was only used, whereas the lowest number was found after the application of chemical weed control alone. Similarly, K w i a t k ow sk i (2009) found a reduction in the number of weed species in a spring barley monoculture as a result of herbicide use (by 18\%). In the present experiment, Avena fatua was the dominant species in the mechanically weeded plot. The following species also occurred in quite large numbers: Chenopodium album, Echinochloa crus-gal$l i$, and Setaria viridis. In the plots where mechanical and chemical weed control and chemical weed control alone were used, the species Veronica persica was dominant. Compared to mechanical weed removal, mechanical and chemical weed control eliminated Setaria viridis from the spring wheat crop. On the other hand, the application of herbicides as the only weed management procedure eliminated from the spring wheat crop the species Chenopodium album, which was found in large numbers in the treatment with mechanical weed management. Relative to the treatments with mechanical weed control, the application of herbicides as the only weed management procedure eradicated from the spring wheat crop the following species: Artemisia vulgaris, Capsella bursa-pastoris, Cirsium arvense, Chenopodium album, Euphorbia helioscopia, Galinsoga parviflora, Galium aparine, Myosotis arvensis, and Polygonum nodosum.

It was found that weed dry weight in the treatment without cover crops and with mechanical weed control alone affected a significant reduction in spring wheat productivity $(\mathrm{r}=-0.75)$ (Table 5). Spring wheat productivity also showed a significant negative correlation with the number of weeds per unit area in the treatment with mechanical crop control, both in the plots without cover crops $(r=-0.68)$ and in the plots were lacy phacelia was grown $(\mathrm{r}=-0.51)$ (Table 6). The lowest grain yield was found in the above-mentioned treatments, which is evidenced by the results presented in a paper relating to yield of spring wheat grown in the experiment in question $(\mathrm{G} \mathrm{aw}$ e d a and $\mathrm{Kw}$ i a t k ow s k i, 2012). In the opinion of $\mathrm{K} \mathrm{w} \mathrm{i} \mathrm{a} \mathrm{t} \mathrm{k} \mathrm{o} \mathrm{w} \mathrm{s} \mathrm{k} \mathrm{i}$ (2009), productivity and yield components of spring cereals are generally negatively correlated with the number and air-dry weight of weeds in a crop, but a significant correlation coefficient more frequently relates to weed dry weight and has the highest values in years with unfavourable distribution of precipitation.

No significant correlation was found between cover crop biomass yield and weed infestation of the spring wheat crop (Table 7). Nevertheless, we observed a clear trend towards a reduction in weed dry weight in the plots sown with white mustard and with complete weed control (mechanical and chemical control). Lacy phacelia proved to be a species conducive to an increase in weight of weeds in the cereal crops $(\mathrm{r}=0.13-0.28)$. According to some authors $(\mathrm{M} \mathrm{u} \mathrm{r} \mathrm{a}$ w a et al. 2004), the number and weight of weeds in a crop are reduced mainly through the successful use of cover crops that produce large biomass (legumes, rape, mustard). In the present study, the highest biomass yield was obtained from the white mustard crops, while the lowest one from lacy phacelia, which was reflected in the effect on weed infestation of the cereal plant in question (Table 8). The search for the cause and effect relationship between cover crop biomass and weed infestation requires further detailed research. The existing literature of the subject shows that cover crops (in par- 
ticular species of the family Brassicacae) may inhibit weed growth through their secretions. The allelopathic potential of Brassicacae plants is manifested mainly in dead stems and leaves and it is higher when plant parts are mixed with the soil (cover crop biomass ploughed in) (O l e s ze k et al. 1994; M u raw a et al. 2004).

Table 1

Mean monthly air temperature and total rainfall in 2009-2011 compared to long-term averages in 1964-2011, according to the Uhrusk Meteorological Station

\begin{tabular}{|c|c|c|c|c|c|c|}
\hline \multirow{3}{*}{ Year } & \multicolumn{6}{|c|}{ Months } \\
\hline & IV & V & VI & VII & VIII & IV-VIII \\
\hline & \multicolumn{5}{|c|}{ Total rainfall (mm) } & Total \\
\hline 2009 & 27.0 & 81.5 & 169.3 & 42.7 & 60.0 & 380.5 \\
\hline 2010 & 34.4 & 150.5 & 72.6 & 57.5 & 128.5 & 443.5 \\
\hline 2011 & 34.5 & 42.0 & 87.4 & 147.2 & 64.1 & 375.2 \\
\hline \multirow[t]{2}{*}{ Averages 1964-2011 } & 39.1 & 65.5 & 73.7 & 86.5 & 70.2 & 335.0 \\
\hline & \multicolumn{5}{|c|}{ Temperature $\left({ }^{\circ} \mathrm{C}\right)$} & Mean \\
\hline 2009 & 10.0 & 13.1 & 16.4 & 20.0 & 17.8 & 15.5 \\
\hline 2010 & 8.8 & 14.8 & 18.6 & 21.6 & 19.7 & 16.7 \\
\hline 2011 & 10.2 & 14.2 & 18.5 & 20.1 & 18.5 & 16.3 \\
\hline Averages 1964-2011 & 7.8 & 13.6 & 16.6 & 18.3 & 17.5 & 14.8 \\
\hline
\end{tabular}

Table 2

Number of weeds in the spring wheat crop depending on the cover crop and weed control method in 2009-2011 (in plants $\times \mathrm{m}^{-2}$ )

\begin{tabular}{|c|c|c|c|c|c|c|c|c|c|c|c|c|c|c|c|c|c|c|c|}
\hline \multirow[b]{2}{*}{ Year } & \multicolumn{4}{|c|}{ Without cover crop } & \multicolumn{4}{|c|}{ White mustard } & \multicolumn{4}{|c|}{ Lacy phacelia } & \multicolumn{4}{|c|}{ Legume mixture } & \multicolumn{3}{|c|}{ Mean } \\
\hline & $a^{*}$ & $\mathrm{~b}$ & $\mathrm{c}$ & $\stackrel{\Xi ّ}{\Sigma}$ & $\mathrm{a}$ & $\mathrm{b}$ & $\mathrm{c}$ & $\sum_{\Sigma}^{\Xi}$ & $\mathrm{a}$ & $\mathrm{b}$ & $\mathrm{c}$ & $\stackrel{\Xi \Xi}{\Sigma}$ & a & $\mathrm{b}$ & $\mathrm{c}$ & $\stackrel{\Xi \Xi}{\Sigma}$ & $\mathrm{a}$ & $\mathrm{b}$ & $\mathrm{c}$ \\
\hline 2009 & 13.3 & 3.7 & 15.0 & 10.7 & 24.3 & 14.3 & 12.0 & 16.9 & 28.3 & 12.7 & 14.7 & 18.6 & 20.0 & 17.3 & 15.7 & 17.7 & 21.5 & 12.0 & 14.4 \\
\hline 2010 & 6.0 & 4.6 & 3.0 & 4.5 & 13.0 & 14.0 & 9.0 & 12.0 & 7.7 & 9.3 & 4.0 & 7.0 & 5.0 & 1.9 & 3.3 & 3.4 & 7.9 & 7.4 & 4.8 \\
\hline 2011 & 82.7 & 14.3 & 10.3 & 35.8 & 12.7 & 7.3 & 13.0 & 11.0 & 70.7 & 10.7 & 18.0 & 33.1 & 47.7 & 10.3 & 10.3 & 22.8 & 53.4 & 10.6 & 12.9 \\
\hline Mean & 34.0 & 7.5 & 9.4 & 17.0 & 16.7 & 11.9 & 11.3 & 13.3 & 35.6 & 10.9 & 12.2 & 19.6 & 24.2 & 9.8 & 9.8 & 14.6 & 27.6 & 10.0 & 10.7 \\
\hline $\operatorname{LSD}_{0.05}$ & $\begin{array}{l}\text { cove } \\
\text { cove }\end{array}$ & $\sigma_{1}$ & 2. & weec & contr & ol met & 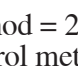 & $22 ; \mathrm{co}$ & ver cr & ops x & d & 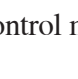 & tho & $=6.2$ & & & & & \\
\hline
\end{tabular}

*a: mechanical weed control

b: mechanical and chemical weed control

c: chemical weed control

Table 3

Air-dry weight of weeds in the spring wheat crop depending on the cover crop and weed control method in $2009-2011\left(\right.$ in $\left.\mathrm{g} \times \mathrm{m}^{-2}\right)$

\begin{tabular}{|c|c|c|c|c|c|c|c|c|c|c|c|c|c|c|c|c|c|c|c|}
\hline \multirow[b]{2}{*}{ Year } & \multicolumn{4}{|c|}{ Without cover crop } & \multicolumn{4}{|c|}{ White mustard } & \multicolumn{4}{|c|}{ Lacy phacelia } & \multicolumn{4}{|c|}{ Legume mixture } & \multicolumn{3}{|c|}{ Mean } \\
\hline & $a^{*}$ & $\mathrm{~b}$ & $\mathrm{c}$ & $\sum_{\Sigma}^{\mathbb{E}}$ & $\mathrm{a}$ & $\mathrm{b}$ & $\mathrm{c}$ & 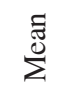 & $\mathrm{a}$ & $\mathrm{b}$ & $\mathrm{c}$ & 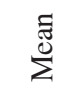 & $\mathrm{a}$ & $\mathrm{b}$ & $\mathrm{c}$ & $\sum_{\Sigma}^{\Xi}$ & $\mathrm{a}$ & $\mathrm{b}$ & $\mathrm{c}$ \\
\hline 2009 & 11.4 & 2.5 & 2.7 & 5.5 & 4.5 & 1.7 & 2.2 & 2.8 & 8.7 & 1.9 & 2.1 & 4.2 & 5.2 & 2.8 & 4.1 & 4.0 & 7.5 & 2.2 & 2.8 \\
\hline 2010 & 18.3 & 4.5 & 1.3 & 8.0 & 11.7 & 0.9 & 6.6 & 6.4 & 2.1 & 1.0 & 0.7 & 1.3 & 1.5 & 0.5 & 0.5 & 0.8 & 8.4 & 1.7 & 2.3 \\
\hline 2011 & 77.6 & 3.4 & 2.5 & 27.8 & 4.2 & 0.7 & 3.2 & 2.7 & 29.9 & 1.5 & 4.3 & 11.9 & 30.5 & 2.4 & 3.3 & 12.1 & 35.6 & 2.0 & 3.3 \\
\hline Mean & 35.8 & 3.5 & 2.2 & 13.8 & 6.8 & 1.1 & 4.0 & 4.0 & 13.6 & 1.5 & 2.4 & 5.8 & 12.4 & 1.9 & 2.6 & 5.6 & 17.2 & 2.0 & 2.8 \\
\hline $\mathrm{LSD}_{0.05}$ & $\begin{array}{l}\mathrm{cov} \\
\mathrm{cov}\end{array}$ & , & -1 & we & cont & $\mathrm{lm}$ & $\mathrm{od}=$ & 34 & ver c & rops & & & & & & & & & \\
\hline
\end{tabular}

*a: mechanical weed control

b: mechanical and chemical weed control

c: chemical weed control 
Table 4

Weed species in the spring wheat crop depending on the cover crop and weed control method, in plants $\times \mathrm{m}^{-2}$ (mean for 2009-2011)

\begin{tabular}{|c|c|c|c|c|c|c|c|}
\hline \multirow{2}{*}{ Weed species } & \multicolumn{4}{|c|}{ Cover crop* } & \multicolumn{3}{|c|}{ Weed control method** } \\
\hline & A & $\mathrm{B}$ & $\mathrm{C}$ & $\mathrm{D}$ & $\mathrm{a}$ & $\mathrm{b}$ & $\mathrm{c}$ \\
\hline \multicolumn{8}{|c|}{ Annuals } \\
\hline Amaranthus retroflexus $\mathrm{L}$. & 0.4 & 0.7 & 1.1 & 1.0 & 2.0 & 0.1 & 0.4 \\
\hline Anagallis arvensis L. & 0.4 & 0.8 & 1.0 & 0.3 & 0.5 & 0.5 & 0.9 \\
\hline Avena fatua $\mathrm{L}$ & 6.1 & 0.2 & 0.3 & 1.5 & 6.0 & 0.1 & 0.0 \\
\hline Capsella bursa-pastoris (L.) Medik. & $0.0^{* * * *}$ & - & 0.1 & 0.0 & 0.1 & 0.1 & - \\
\hline Chenopodium album $\mathrm{L}$. & 0.7 & 0.5 & 2.7 & 1.0 & 3.6 & 0.1 & - \\
\hline Echinochloa crus-galli (L.) P. Beauv. & 4.3 & 1.1 & 1.0 & 0.4 & 2.7 & 1.7 & 0.8 \\
\hline Erodium cicutarium (L.) L' Hér. & 0.0 & - & 0.1 & - & - & 0.1 & - \\
\hline Euphorbia helioscopia L. & - & 0.1 & - & - & 0.0 & 0.1 & - \\
\hline Fallopia convolvulus (L.) Á. Löve & 0.9 & 2.3 & 1.4 & 1.2 & 1.8 & 1.2 & 1.4 \\
\hline Galinsoga parviflora Cav. & 0.0 & - & - & - & 0.0 & - & - \\
\hline Galium aparine $\mathrm{L}$. & 0.0 & - & - & - & 0.0 & - & - \\
\hline Geranium pusillum Burm. f. ex L. & 0.1 & - & 0.3 & - & 0.1 & 0.1 & 0.1 \\
\hline Lamium amplexicaule $\mathrm{L}$. & 0.0 & 0.0 & 0.3 & 1.5 & 0.2 & 0.6 & 0.6 \\
\hline Matricaria maritima ssp. inodora (L.) Dostál & 0.3 & - & 0.1 & - & 0.2 & - & 0.1 \\
\hline Melandrium album (Mill.) Garcke & 0.2 & 0.9 & 0.8 & 0.5 & 0.9 & 0.4 & 0.6 \\
\hline Myosotis arvensis (L.) Hill & 0.0 & 0.1 & - & - & 0.1 & 0.0 & - \\
\hline Papaver rhoeas $\mathrm{L}$. & - & - & 0.1 & - & - & 0.1 & - \\
\hline Polygonum aviculare $\mathrm{L}$. & 1.0 & 2.0 & 0.6 & 0.4 & 1.8 & 0.5 & 0.7 \\
\hline Polygonum nodosum Pers. & - & - & 0.1 & - & 0.1 & - & - \\
\hline Setaria viridis (L.) P. Beauv. & 0.1 & 0.1 & 3.0 & 0.1 & 2.4 & - & 0.0 \\
\hline Solanum nigrum L. Emend. Mill. & 0.3 & 0.1 & 0.5 & 0.2 & 0.5 & 0.2 & 0.1 \\
\hline Sonchus asper (L.) Hill & 0.2 & 0.3 & 0.4 & 0.5 & 0.6 & 0.2 & 0.3 \\
\hline Stellaria media (L.) Vill. & 0.2 & 0.1 & 0.6 & 0.8 & 0.7 & 0.1 & 0.5 \\
\hline Veronica persica Poir. & 0.9 & 2.3 & 2.8 & 3.4 & 2.1 & 2.1 & 2.9 \\
\hline Viola arvensis Murray & 0.1 & 0.6 & 1.1 & 0.8 & 0.6 & 0.5 & 0.8 \\
\hline \multicolumn{8}{|c|}{ Perennials } \\
\hline Artemisia vulgaris L. & - & 0.0 & - & - & 0.0 & - & - \\
\hline Cerastium arvense $\mathrm{L}$. & - & - & 0.0 & - & - & 0.0 & - \\
\hline Cirsium arvense (L.) Scop. & 0.2 & - & 0.1 & 0.0 & 0.1 & 0.1 & - \\
\hline Convolvulus arvensis L. & - & - & 0.6 & 0.3 & 0.1 & 0.4 & 0.2 \\
\hline Elymus repens (L.) Gould & 0.2 & 0.9 & 0.2 & 0.0 & 0.1 & 0.8 & 0.1 \\
\hline Plantago intermedia Gilib. & 0.2 & 0.1 & 0.1 & 0.0 & 0.0 & 0.1 & 0.2 \\
\hline Plantago major L. & 0.0 & - & - & - & - & - & 0.0 \\
\hline Sonchus arvensis $\mathrm{L}$. & - & 0.0 & 0.1 & 0.4 & 0.4 & 0.0 & 0.0 \\
\hline Taraxacum officinale F. H. Wigg. & 0.2 & 0.1 & 0.1 & 0.3 & 0.2 & 0.1 & 0.2 \\
\hline Trifolium repens $\mathrm{L}$. & 0.0 & - & - & - & - & - & 0.0 \\
\hline Total number of species & 28 & 22 & 28 & 22 & 30 & 27 & 23 \\
\hline
\end{tabular}

* A: control treatment; B: white mustard; C: lacy phacelia; D: narrow-leaf lupin + field pea

** a: mechanical weed control; b: mechanical and chemical weed control; c: chemical weed control

$* * * 0.0$ : species occurring at $<0.1$

Table 5

Coefficients of correlation (r) between air-dry weight of weeds and spring wheat grain yield - mean for 2009-2011

\begin{tabular}{lccc}
\hline \multicolumn{1}{c}{ Cover crop } & \multicolumn{3}{c}{ Weed control method } \\
\cline { 2 - 4 } & mechanical & mechanical and chemical & chemical \\
\hline Without cover crop (control treatment) & $-0.75^{*}$ & -0.29 & -0.17 \\
White mustard & -0.22 & -0.07 & -0.09 \\
Lacy phacelia & -0.35 & -0.10 & -0.12 \\
Legume mixture & -0.44 & -0.31 & -0.39 \\
*significant correlation coefficient $(0.05)$ & & & \\
\hline
\end{tabular}


Table 6

Coefficients of correlation (r) between the number of weeds and spring wheat grain yield - mean for 2009-2011

\begin{tabular}{lccc}
\hline \multicolumn{1}{c}{ Cover crop } & \multicolumn{3}{c}{ Weed control method } \\
\cline { 2 - 4 } & mechanical & mechanical and chemical & chemical \\
\hline Without cover crop (control treatment) & $-0.68^{*}$ & -0.17 & -0.36 \\
White mustard & -0.30 & -0.12 & -0.20 \\
Lacy phacelia & $-0.51^{*}$ & -0.24 & -0.35 \\
Legume mixture & -0.38 & -0.27 & -0.28 \\
\hline *significant correlation coefficient (0.05) & & &
\end{tabular}

Table 7

Coefficients of correlation (r) between air-dry weight of cover crops and air-dry weight of weeds in the spring wheat crop (mean for 2009-2011)

\begin{tabular}{lcccc}
\hline \multirow{2}{*}{ Weed control method } & \multicolumn{3}{c}{ Cover crops in spring wheat monoculture } \\
\cline { 2 - 5 } & white mustard & lacy phacelia & legume mixture & Mean \\
\hline Mechanical & 0.02 & 0.28 & 0.19 & 0.16 \\
Mechanical and chemical & -0.41 & 0.13 & -0.11 & -0.13 \\
Chemical & -0.28 & 0.19 & -0.06 & -0.05 \\
Mean & -0.22 & 0.20 & 0.01 & - \\
\hline * significant correlation coefficient (0.05) & & &
\end{tabular}

Table 8

Air-dry yield of cover crops in 2008-2010 (in $\mathrm{t} \times \mathrm{ha}^{-1}$ )

\begin{tabular}{cccc}
\hline \multirow{2}{*}{ Year } & \multicolumn{3}{c}{ Cover crops in spring wheat monoculture } \\
\cline { 2 - 4 } & white mustard & lacy phacelia & legume mixture \\
\hline 2008 & 3.38 & 3.15 & 2.17 \\
2009 & 2.60 & 2.54 & 3.00 \\
2010 & 2.75 & 2.18 & 2.89 \\
Mean & 2.91 & 2.62 & 2.69 \\
\hline
\end{tabular}

\section{CONCLUSIONS}

1. The white mustard stubble crop significantly reduced the number of weeds. Growing wheat in the plot with lacy phacelia ploughed in proved to be the least beneficial.

2. The ploughing in of white mustard and of the mixture of narrow-leaf lupin with field pea had a reducing effect on the number of weed species.

3 . The triple harrowing proved to be ineffective in reducing the number and air-dry weight of weeds. At the same time, the spring wheat crop with mechanical weed control was characterized by the highest floristic diversity of weed communities.

4. Mechanical weed management in spring wheat cultivation reduces weed infestation in the presence of stubble crops.

5. Weeds significantly reduced grain yield of spring wheat grown after itself without cover crops and with mechanical weed control alone.
6. Cover crop biomass yield and biomass incorporation into the soil did not have a significant consequential effect on weed infestation of spring wheat.

\section{Acknowledgements}

Research supported by the Ministry of Science and Higher Education of Poland as the part of statutory activities of Department of Herbology and Plant Cultivation Techniques, University of Life Sciences in Lublin.

\section{REFERENCES}

Akemo M., Regnier E., Bennet M. 2000. Weed suppression in spring-sown rye (Secale cereale) - Pea (Pisum sativum) cover crop mixes. Weed Technol. 14: 545-549.

Duer I. 1994. Wpływ międzyplonu ścierniskowego na plonowanie i zachwaszczenie jęczmienia jarego. / Effect of catch crops on yield and weed infestation of spring 
barley. Fragm. Agron. 11(4): 36-45 (in Polish).

Dworakowski T. 1998. Działanie międzyplonu ścierniskowego w ogniwie zmianowania zboża ozime - zboża jare. / Effectiveness of catch crop in cereal crop rotation. Fragm. Agron. 15(3): 90-99 (in Polish).

Gawęda D. 2009. Wpływ międzyplonów ścierniskowych na zachwaszczenie pszenicy jarej uprawianej w monokulturze. / The influence of stubble crops on weed infestation of spring wheat grown in monoculture. Ann. UMCS, Sect. E, 64(3): 21-28 (in Polish).

Gawęda D., Kwiatkowski C. 2012. Plonowanie pszenicy jarej uprawianej w krótkotrwałej monokulturze w zależności od międzyplonu i sposobu odchwaszczania. / Yield of spring wheat grown in short-term monoculture depending on catch crop and weed control method. Ann. UMCS, Sect. E, 67(2): 50-58 (in Polish).

Hauggaard-Nielsen H., Ambus P., Jensen E.S. 2001. Interspecific competition, $N$ use interference with weeds in pea-barley intercropping. Field Crops Res. 70: 101-109.

Jaskulski D., Tomalak S., Rudnicki F. 2000. Regeneracja stanowiska po pszenicy ozimej dla jęczmienia jarego przez rośliny międzyplonu ścierniskowego. / Regeneration of the stand after winter wheat for spring barley with catch crop plants. Zesz. Probl. Post. Nauk Rol. 470: 49-57 (in Polish).

Kuś J., J oń czyk K. 1999. Wpływ międzyplonów i sposobu uprawy roli na plonowanie roślin i zawartość azotu mineralnego w glebie. / The effect of intercrops and the method of their cultivation on crop yielding and content of mineral nitrogen in soil. Rocz. Nauk. Rol. 114(3-4): 83-95 (in Polish).

Kwiatkowski C. 2004. Wpływ międzyplonu na plonowanie i zachwaszczenie jęczmienia jarego uprawianego $\mathrm{w}$ monokulturze./ The effect of intercrops on yields and weed infestation of spring barley cultivated in monoculture. Ann. UMCS, Sect. E, 59(2): 809-815 (in Polish).

Kwiatkowski C. 2009. Studia nad plonowaniem jęczmienia jarego nagoziarnistego i oplewionego w płodozmianie i monokulturze. / Studies on the yielding of naked and husked spring barley in crop rotation and monoculture. Rozpr. Nauk. UP Lublin, 336: 117 (in Polish).

Murawa D., Pykało I., Banaszkiewicz T. 2004. Kompleksowa ocena chwastobójcza substancji aktywnych w gorczycy białej (Sinapis alba L.). / Complex evaluation of weed control by active substances in the white mustard (Sinapis alba L.). Rośliny Oleiste XXV: 521-531 (in Polish).

Oleszek W., Ascard J., Johansson H. 1994. Brassicacae jako rośliny alternatywne umożliwiające kontrolę zachwaszczenia w rolnictwie zachowawczym. / Brassicacae as alternative plants for weed control in sustainable agriculture. Fragm. Agron. 11(4): 5-19 (in Polish).

Teasdale J.R., Beste C.E., Potts W.E. 1991. Response of weeds to tillage and cover crop residue. Weed Sci. 39: 195-199.

Wojcie chowsk i W. 1998. Międzyplony ścierniskowe jako czynnik zapobiegający negatywnym skutkom wysycenia struktury zasiewów zbożami. / Stubble catch-crops as a factor preventing negative effects of cereal abundance in crop rotation system. Post. Nauk Rol. 5: 29-36 (in Polish).

Woj cie chowski W. 2009. Znaczenie międzyplonów ścierniskowych w optymalizacji nawożenia azotem jakościowej pszenicy jarej. / The importance of catch crops for optimizing nitrogen fertilization of quality spring wheat. Monografie UP Wrocław, 74: 122 (in Polish).

Woźniak A. 2005. Wpływ wsiewek międzyplonowych i nawożenia organicznego na plonowanie i zachwaszczenie pszenicy jarej uprawianej w monokulturze. / Importance of underplant crop and farmyard as manures on the yield and weed infestation in a monoculture of spring wheat. Ann. UMCS, Sect. E, 60: 33-40 (in Polish).

\section{Zachwaszczenie formy jarej pszenicy zwyczajnej (Triticum aestivum L.) uprawianej w monokulturze w zależności od międzyplonu i sposobu odchwaszczania}

\section{Streszczenie}

Celem trzyletnich badań polowych była ocena wpływu wybranych międzyplonów ścierniskowych i sposobu odchwaszczania zasiewów na skład gatunkowy, liczbę oraz powietrznie suchą masę chwastów w łanie pszenicy jarej uprawianej w krótkotrwałej monokulturze. Badania realizowano w latach 2009-2011 w Gospodarstwie Doświadczalnym Uhrusk, na rędzinie mieszanej zaliczanej do kompleksu żytniego bardzo dobrego. Uwzględniono w nich rodzaje przyorywanych corocznie międzyplonów ścierniskowych (bez międzyplonów - obiekt kontrolny, gorczyca biała, facelia błękitna, mieszanka strączkowych - łubin wąskolistny + groch siewny pastewny) oraz sposób odchwaszczania pszenicy jarej (pielęgnacja mechaniczna, mechaniczno-chemiczna i chemiczna). Średnio za okres badań na obiektach z mechaniczną pielęgnacją zasiewów wszystkie zastosowane międzyplony ścierniskowe ograniczyły powietrznie suchą masę chwastów względem obiektu kontrolnego. Niezależnie od sposobu odchwaszczania liczba chwastów w łanie pszenicy była istotnie mniejsza jedynie po przyoraniu gorczycy białej. Mechaniczna walka z chwastami okazała się mniej skuteczna w redukcji liczby i powietrznie suchej masy chwastów w porównaniu do pozostałych sposobów pielęgnacji. Międzyplony z gorczycy białej oraz mieszanki roślin strączkowych wpłynęły ograniczająco na liczbę gatunków chwastów w odniesieniu do obiektu bez międzyplonów. Największą różnorodność florystyczną zbiorowisk chwastów stwierdzono w łanie pszenicy jarej odchwaszczanej wyłącznie mechanicznie. 